\title{
Genetics and Biodiversity Journal
}

Journal homepage: http://ojs.univ-tlemcen.dz/index.php/GABJ

Original Research Paper

\section{Morphological characterization of an Algerian Sighthound known as The Sloughi raised in the Wilaya of Tlemcen, Northwest of Algeria.}

\author{
Haddam H.Y' ${ }^{1}$, Mennani A ${ }^{\mathbf{2}}$, Hamel W¹, Benhamadi M¹, Gaouar S.B.S ${ }^{\mathbf{1}}$. \\ ${ }^{1}$ Department of Biology, Faculty of Sciences of Nature and Life, Earth and Universe Sciences Abou \\ Bekr Belkaid, Tlemcen, Algeria; \\ ${ }^{2}$ Department of Biology, Faculty of Sciences of Nature and Life, Ferhat Abbes, Setif, Algeria.
}

Corresponding Author: HADDAM Hadi Youssouf, Abou Bekr BELKAID University, Tlemcen, Algeria; Email: hyh.genetics@gmail.com .

Article history; Received: July $7^{\text {th }} 2020$; Revised: August $28^{\text {th }} 2020$; Accepted: 2 December $5^{\text {th }} 2020$.

\begin{abstract}
The "Sloughi" is a North African sighthound that the World Canine Organization recognizes as a Moroccan greyhound

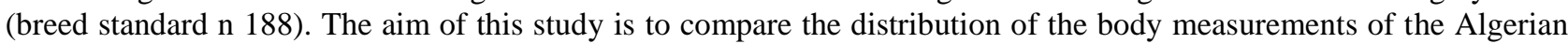
sighthound by sex, sampling zones and body coat color. Sixteen morphometric variables were measured and six indices were estimated (format, massiveness, bone, head/neck, muzzle/head, withers/rump) in 30 adult unrelated animals (21 males and 9 females). The impact of sex on variables and indices was assessed using the t-test, while that of the sampling zones and that of the coat color using ANOVA. The mean values for withers height, height at rump, head length, muzzle length, ears length, neck length, body length, tail length, muzzle circumference, head circumference, neck circumference, chest circumference, waist circumference, thigh circumference, forearm circumference, wrist circumference were $71.85,70.61,25.24,10.83,13.16,21.23,68.44,43.55,21.50,33.63,41.27,73.35,48.73,34.48$, 14.67 and $10.81 \mathrm{~cm}$, respectively. The results showed that there was no sexual dimorphism according to the phenotypic traits, the difference between the animals was only due to their body measurements. Males had more developed measurable traits than females, and the mean of Shannon's diversity index for all variables was 0.99363 .
\end{abstract}

Keywords: Body indices, Morphometric characterization, Sighthound dog, Sloughi.

\section{Introduction}

The dog is the first animal that was domesticated, and that more than 30,000 years ago, this is what scientists suggest using fossil evidence (Germonpre et al., 2009). Hunting was the first purposes of this domestication, but scientists have not yet agreed on the exact geographical area of this domestication (O. Yilmaz, 2017). The Sloughi is a typical North African sighthound that was present among the ancient Egyptians because there are many depictions of floppy-eared greyhounds in ancient Egypt, some quite famous. For example, they are depicted running under Tutankhamun's chariot while he is fighting or hunting gazelles in the desert (Crapon et al., 2004, Keys, 2004).

The International Cynological Federation FCI is the world's leading canine organization. The classification of dogs is made by the FCI, it has divided the dog breeds into 10 groups, which, in turn, are subdivided into a variable number of sections. Finally, each breed is assigned a numerical identification code. Currently, the FCI recognizes 353 breeds. Classification is made mainly according to physical standards and attitudinal traits. Some dog breeds are provisionally recognized by the FCI, and others are simply not yet recognized. The FCI nomenclature is therefore likely to accommodate variable number of breeds. (www.fci.be, last updated April, 27 2020 , consulted on September, $30^{\text {th }}$ 2020). 
Sighthound breeds can be classified into three categories according to reported sizes: small-, mid- and bigsized hounds for height at withers below $50 \mathrm{~cm}$, between 51 and $70 \mathrm{~cm}$ and above $70 \mathrm{~cm}$, respectively $(O$. Y1lmaz and M. Ertuğrul, 2011). There are many examples of big-sized hounds who are higher than $70 \mathrm{~cm}$ at withers like English Greyhound, Russian Borzoi, Scottish Deerhound and Irish Wolfhound. These dogs are also classified into three sections according to their hair type: long-, wire- and short-hair like Afghan hound, Russian Barzoi and Sloughi, respectively. (Pugnetti, 2001).

Although the Sloughi is present everywhere in North Africa, Morocco is the only country that holds a standard of this breed. In Algeria, the Sloughi is used for hunting the African golden wolf, the gazelle, and the hares in different regions of the country. It is also used in dog sports such as running. Breeders favor Sloughi over the Spanish Galgo, the British Greyhound and others sighthound breeds because of its endurance in long distance races according to their statements.

These dogs are reared for their resistance to different climates, superior hunting skills, mild and affectionate character. The aim of this study was a morphological characterization of the local Algerian sighthound in the Wilaya of Tlemcen in order to provide the knowledge basis for a better breed identification and management of the genetic diversity in this relevant biological resource.

\section{Materials and methods}

\section{Study area.}

The Wilaya of Tlemcen occupies a prime position in within the national whole. It is located on the northwest coast of the country and has a seafront of $120 \mathrm{~km}$. It is a border Wilaya with Morocco, with an area of $9,017.69 \mathrm{~km}^{2}$. The Mediterranean Sea in the North, the Wilaya of Ain Témouchent in the east, the Wilaya of Sidi Bel Abbes in the East-South-East, the Wilaya of Naama in the South, and finally Morocco in the West limit Tlemcen. The Wilaya of Tlemcen has a Mediterranean climate, based on the opposition between an oceanic winter where the Wilaya is open to maritime depressions and a desert summer with persistent heat throughout the season. Rainfall is generally subject to a double irregularity between seasonal and intranasal. In winter, the temperature can drop below $0{ }^{\circ} \mathrm{C}$, and in summer, it can reach $45^{\circ} \mathrm{C}$.

Our study was done in the Wilaya of Tlemcen in seven different zones where the distribution of breeders is more important, these zones are named Remchi, Sabra, Chlayda, Bensakrane, Hennaya, and Ouzidane, all of them are pure agricultural regions with many farms from colonial time, and Ain Nehala is the first agricultural socialist village inaugurated in 1972, this village is located in the border of the Wilaya of Tlemcen and the Wilaya of Sidi Bel-Abbes. There was no coastal region in our study. 


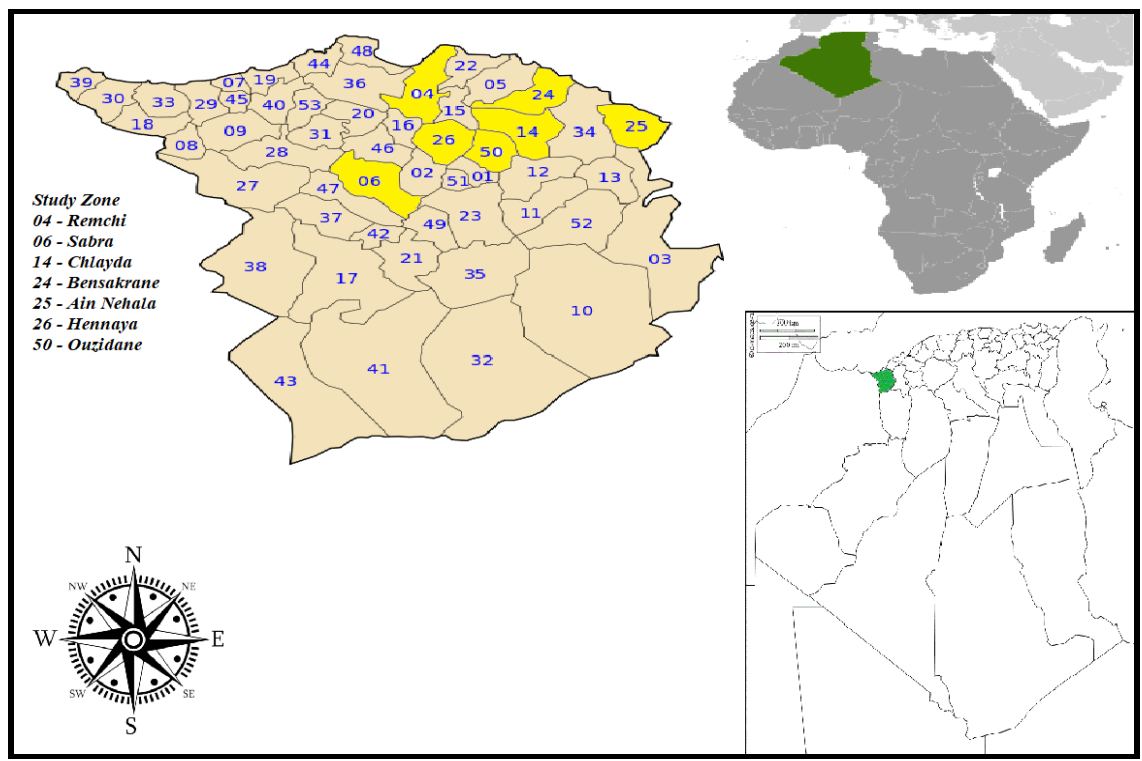

Figure 1. Representation of the study zones in Tlemcen.

\section{Choice of animals:}

Our work was based on the study of the morphological traits of 30 unrelated Algerian sighthounds because we excluded from our study all individuals who had a family link, all adults between three and five years old, and presumed purebreds. We made sure that all the individuals chosen and studied were in perfect health and showed no signs of any disease. Before doing any manipulation on the animals, blood sampling or measurements, the breeders and owners of the dogs were totally agreeing. The individuals are grouped according to zones and sex as showed in the table below.

Table 1. Distribution of the study sample set by zones, sex and labels.

\begin{tabular}{lccc}
\hline Zones & Males \& Labels & Females \& Labels & Total \\
\hline Hennaya & $\mathbf{5}(\mathrm{T} 1, \mathrm{~T} 3, \mathrm{~T} 4, \mathrm{~T} 5, \mathrm{~T} 7)$ & $\mathbf{3}(\mathrm{T} 2, \mathrm{~T} 6, \mathrm{~T} 8)$ & 8 \\
Ouzidane & $\mathbf{2}(\mathrm{T} 9, \mathrm{~T} 10)$ & $\mathbf{0}$ & $\mathbf{0}$ \\
Chlayda & $\mathbf{1}(\mathrm{T} 11)$ & $\mathbf{2}(\mathrm{T} 13, \mathrm{~T} 14)$ & 1 \\
Sabra & $\mathbf{1}(\mathrm{T} 12)$ & $\mathbf{1}(\mathrm{T} 17)$ & $\mathbf{0}$ \\
Bensakrane & $\mathbf{5}(\mathrm{T} 15, \mathrm{~T} 16, \mathrm{~T} 18, \mathrm{~T} 19, \mathrm{~T} 20)$ & $\mathbf{0}$ & 3 \\
Remchi & $\mathbf{3}(\mathrm{T} 21, \mathrm{~T} 22, \mathrm{~T} 23)$ & $\mathbf{3}(\mathrm{T} 24, \mathrm{~T} 25, \mathrm{~T} 26)$ & 7 \\
Ain Nehala & $\mathbf{4}(\mathrm{T} 27, \mathrm{~T} 28, \mathrm{~T} 29, \mathrm{~T} 30)$ & $\mathbf{9}$ & $\mathbf{3 0}$ \\
\hline Total & $\mathbf{2 1}$ & &
\end{tabular}

\section{Morphometric variables.}

Sixteen quantitative traits and six estimated indices have been chosen in our work as shown in the table below. (Gonzàlez et al., 2011, Drobnjak et al., 2010, Drobnjak, 2012).

The measurements were taken by an ordinary tape measure for all quantitative variables because dogs were afraid of the measuring board. We recorder also gender and coat colors. This work was carried out during different times of the day depending on the availability of the breeders (morning, afternoon, and evening). Points of measurements are shown in Figure 2; the method used has been applied to different domestic animals (Herrera et al., 1996). Body indices values were calculated by the formulas shown below (Drobnjak et al., 2010, Drobnjak, 2012), (FCI STANDARD N¹88). 
Table 2. Morphometric traits studied in the considered sighthound dogs.

\begin{tabular}{ccc}
\hline $\begin{array}{c}\text { Abbreviatio } \\
\text { n }\end{array}$ & Measurements & Details \\
\hline HW & Height at Withers & Range between ground level to highest peak of withers \\
HR & Height at Rump & Range between ground level to highest level of sacrum \\
HL & Head Length & Range between the tip of the truffle and the interparietal bone \\
ML & Muzzle Length & Range between eye arches to nose point \\
EL & Ears Length & Vertical range between ear points to depth \\
NL & Neck Length & Range between interparietal bone and the last cervical vertebra (C7). \\
BL & Body Length & Distance between the point of the shoulder and the tip of the hip \\
TL & Tail Length & Distance between upper base and the tip of the tail \\
MC & Muzzle Circumference & Circumference taken from the base of the muzzle \\
HC & Head Circumference & Circumference taken from the widest parts of left and right arcus zygomaticus \\
NC & Neck Circumference & Circumference taken from the base of the neck \\
CC & Chest Circumference & Circumference taken from withers at up and the breastbone below \\
WtC & Waist Circumference & Circumference taken in the abdomen \\
TC & Thigh Circumference & Circumference taken at 7.5 cm above the Stifle (Knee) \\
FC & Forearm Circumference & Circumference taken at 5 cm below the elbow \\
WC & Wrist Circumference & Circumference taken from the thinnest point of metacarpi \\
IOF & Index of Format & Body Length / Height at Withers \\
IOM & Index of Massiveness & Chest Circumference / Height at Withers \\
IOB & Index of Bone & Wrist Circumference / Height at Withers \\
IHN & Index Head-Neck & Head Length / Neck Length \\
IMH & Index Muzzle-Head & Muzzle Length / Head Length \\
IWR & Index Withers-Rump & Height at Withers / Height at Rump \\
\hline
\end{tabular}

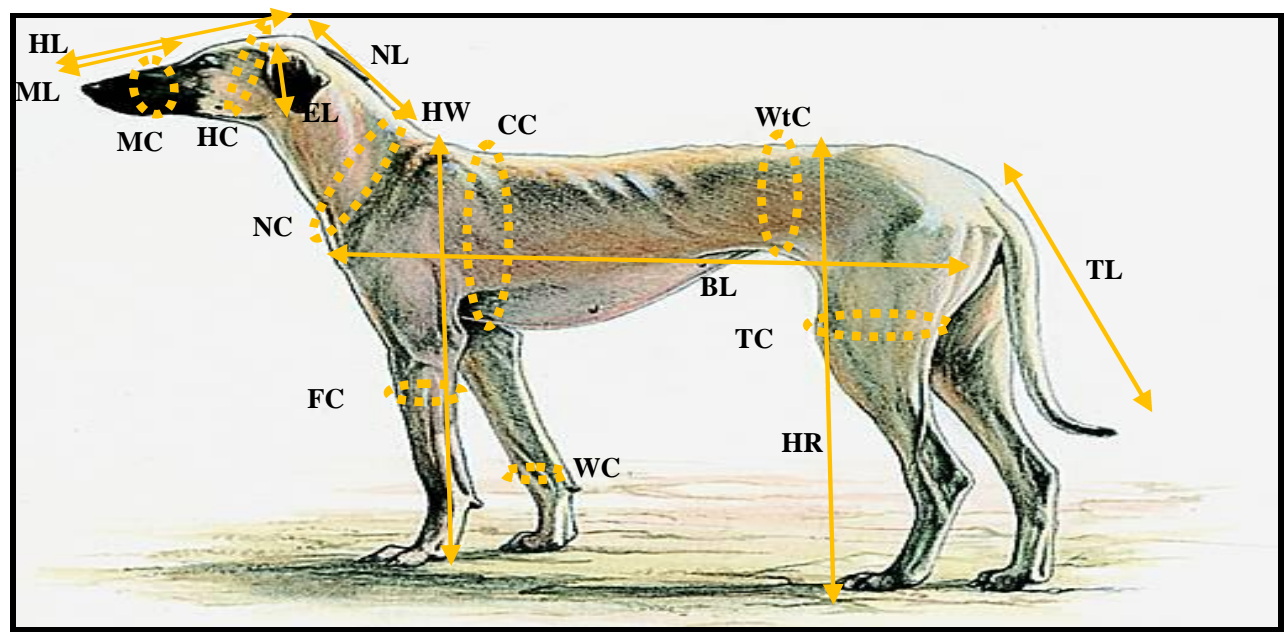

Figure 2. Overview of body measurement points in this study.

\section{Statistical analysis.}

Generally, the examination of morphometric variables using discriminate analysis techniques (simple, stepwise, cluster and canonical) has enabled the differentiation of breeds and varieties of various domestic species (Capote et al., 1998; Crepaldi et al.; 2001; Macciotta et al., 2002; Rodero et al., 2003; Lanari et al., 2003; Zaitoun et al., 2005; Luque et al., 2005; Dossa et al., 2007; Marrube et al., 2007; Vargas et al., 2007; Gonzàlez et al., 2011).

Data were analyzed using IBM SPSS Statistics software (Version.21.0). The impact of sex on body measurements and indices was determined using the t-test and the impact of zone and body coat color on body measurements and indices was assessed using ANOVA. We also investigated the correlation between 
measurement pairs using Pearson's matrix correlation. A Principal Components Analysis (PCA) was performed in order to identify clusters of animals with similar body measurements.

A Hierarchical Ascendant Classification (HAC) was also used to obtain the optimal number of groups in the considered Algerian sighthound sample set. Finally, we calculated the Shannon's index of diversity using Excel software for Windows (Version.2016), Shannon Index is defined and given by the following function:

$H^{\prime}=-\sum_{i=1}^{s} p i * \ln (p i)$

Where $\boldsymbol{p} \boldsymbol{i}$ is the proportion of total sample represented by species $\boldsymbol{i}$. Divide number of individuals of species $\boldsymbol{i}$ by total number of samples. $S$ is the total number of species. H.max $=\ln (S)=$ Maximum diversity possible, and finally $\mathrm{E}=$ Evenness $=\mathrm{H}^{\prime} / \mathrm{Hmax}$.

\section{Results and discussion}

\section{Body measurements.}

Means, standard errors, standard deviations, minima, maxima, and variances of body measurements with ANOVA F-Value and signification are summarized in the table below.

Table 3. Descriptive analysis of body measurements in the studied population in each studied zone.

\begin{tabular}{|c|c|c|c|c|c|c|c|c|}
\hline $\begin{array}{c}\text { Quantitative } \\
\text { traits }(\mathbf{C m})\end{array}$ & Means & SE & SD & Minimum & Maximum & Variance & F Value & $\begin{array}{c}\text { Significance } \\
\text { (among zones) }\end{array}$ \\
\hline HW & 71,85 & 0,78 & 4,28 & 62,8 & 79,3 & 18,29 & 0,701 & ns \\
\hline HR & 70,61 & 0,79 & 4,33 & 60,4 & 78,2 & 18,73 & 0,509 & ns \\
\hline HL & 25,25 & 0,31 & 1,7 & 21,9 & 28,8 & 2,88 & 1,185 & ns \\
\hline ML & 10,83 & 0,18 & 0,97 & 8,1 & 12,4 & 0,93 & 1,604 & ns \\
\hline EL & 13,16 & 0,21 & 1,17 & 10,9 & 15,4 & 1,37 & 0,863 & ns \\
\hline NL & 21,23 & 0,33 & 1,82 & 16,3 & 24,3 & 3,33 & 1,161 & ns \\
\hline BL & 68,44 & 0,88 & 4,82 & 57,8 & 75,3 & 23,19 & 0,308 & ns \\
\hline TL & 43,55 & 0,81 & 4,42 & 34,3 & 51,7 & 19,57 & 1,153 & ns \\
\hline MC & 21,5 & 0,31 & 1,71 & 18,6 & 25,7 & 2,94 & 2,872 & $*$ \\
\hline $\mathrm{HC}$ & 33,64 & 0,42 & 2,28 & 29,3 & 38,7 & 5,2 & 0,743 & ns \\
\hline NC & 41,27 & 0,55 & 3 & 34,2 & 49,3 & 8,97 & 0,976 & ns \\
\hline $\mathrm{CC}$ & 73,36 & 0,72 & 3,97 & 64,8 & 80,5 & 15,76 & 0,55 & ns \\
\hline WtC & 48,74 & 0,92 & 5,03 & 40,3 & 59,1 & 25,28 & 1,376 & ns \\
\hline TC & 34,48 & 0,62 & 3,4 & 27,7 & 41,1 & 11,57 & 0,404 & ns \\
\hline FC & 14,68 & 0,2 & 1,07 & 11,8 & 16,8 & 1,14 & 1,158 & ns \\
\hline WC & 10,81 & 0,19 & 1,06 & 9,1 & 12,8 & 1,12 & 1,192 & ns \\
\hline IOF & 0,953 & 0,009 & 0,052 & 0,862 & 1,038 & 0,003 & 0,597 & ns \\
\hline IOM & 1,022 & 0,09 & 0,044 & 0,932 & 1,109 & 0,002 & 1,395 & ns \\
\hline IOB & 0,150 & 0,002 & 0,012 & 0,129 & 0,175 & 0,00015 & 4,468 & $* *$ \\
\hline IHN & 1,195 & 0,019 & 0,106 & 1,000 & 1,460 & 0,011 & 1,169 & ns \\
\hline IMH & 0,429 & 0,004 & 0,026 & 0,350 & 0,466 & 0,001 & 1,360 & ns \\
\hline IWR & 1,017 & 0,002 & 0,011 & 1,002 & 1,040 & 0,0013 & 0,674 & ns \\
\hline
\end{tabular}

(SE) standard error; (SD) standard deviation, *: Significant $(<0.05), * *:$ very significant $(<0.01)$, ns: not significant.

If only the mean values of $\mathrm{HW}$ and $\mathrm{BL}$ are observed for the total observed sample of Algerian Sighthounds, it can be seen that, generally, Algerian sighthound raised in the Wilaya of Tlemcen have a body whose length is almost equal to the height at withers. Related to the results summarized in Table 3, there was a significant difference between individuals of the different zones for MC and a very significant difference for IOB. These differences can be due to their genetic specificity, the effect of the environment were dogs live, physical activities, food or breeding method like dogs who lives in captivity and free dogs. 
For all the rest of body measurements and body indices, there are no differences between individuals from the different zones.

Results of the impact of sex on both body measurements and body indices using the t-test are shown in the table below.

Table 4. The impact of sex on body measurements and body indices.

\begin{tabular}{cccc}
\hline Gender & Males & Females & \multirow{2}{*}{ Significance } \\
\hline N & $\mathbf{2 1}$ & $\mathbf{9}$ & $* * *$ \\
HW & $73,98 \pm 0,54$ & $66,88 \pm 1,11$ & $* * *$ \\
HL & $72,71 \pm 0,55$ & $65,70 \pm 1,20$ & $* *$ \\
ML & $25,89 \pm 0,30$ & $23,73 \pm 0,44$ & $* *$ \\
EL & $11,16 \pm 0,14$ & $10,06 \pm 0,38$ & $\mathbf{n s}$ \\
NL & $13,36 \pm 0,26$ & $12,70 \pm 0,32$ & $* *$ \\
BL & $21,87 \pm 0,32$ & $19,72 \pm 0,57$ & $* *$ \\
TL & $70,00 \pm 0,77$ & $64,78 \pm 1,86$ & $*$ \\
MC & $44,75 \pm 0,88$ & $40,74 \pm 1,36$ & $* *$ \\
HC & $22,03 \pm 0,30$ & $20,25 \pm 0,60$ & $* *$ \\
NC & $34,38 \pm 0,44$ & $31,88 \pm 0,60$ & $* *$ \\
CC & $42,38 \pm 0,52$ & $38,68 \pm 0,88$ & $* * *$ \\
WtC & $75,01 \pm 0,71$ & $69,48 \pm 0,81$ & $*$ \\
TC & $50,17 \pm 1,04$ & $45,37 \pm 1,32$ & $* * *$ \\
FC & $36,04 \pm 0,56$ & $30,84 \pm 0,65$ & $* *$ \\
WC & $15,12 \pm 0,18$ & $13,63 \pm 0,27$ & $*$ \\
IOF & $11,08 \pm 0,23$ & $10,18 \pm 0,21$ & $\mathbf{n s}$ \\
IOM & $0,946 \pm 0,011$ & $0,967 \pm 0,019$ & $\mathbf{n s}$ \\
IOB & $1,014 \pm 0,010$ & $1,040 \pm 0,013$ & $\mathbf{n s}$ \\
IMN & $0,149 \pm 0,003$ & $0,152 \pm 0,003$ & $\mathbf{n s}$ \\
IWR & $1,188 \pm 0,022$ & $1,211 \pm 0,041$ & $\mathbf{n s}$ \\
\hline
\end{tabular}

$*$ : Significant $(<0.05), * *:$ very significant $(<0.01), * * *$ : highly significant $(<0.001), \mathrm{ns}:$ no significant.

Related to the t-test results, there were significant differences between males and females Algerian sighthound for $\mathrm{TL}, \mathrm{WtC}$ and $\mathrm{WC}(\mathrm{p}<0.05)$, there was a very significant difference for $\mathrm{HL}, \mathrm{ML}, \mathrm{NL}, \mathrm{BL}$, MC, HC and $\mathrm{NC}(\mathrm{p}<0.01)$ and finally a highly significant difference for $\mathrm{HW}, \mathrm{HR}, \mathrm{CC}$, TC and FC $(\mathrm{p}<0.001)$.

For significant, very significant and highly significant traits, males' Algerian sighthound showed higher results than females and this type of difference is very common in different breeds of dogs like Turkish Tazi and Spanish Podenco (O.Yılmaz and M.Ertuğrul, 2011, Gonzàlez et al., 2011). Regarding body indices there were no differences between males and females Algerian's sighthound.

Table 5. Some sighthound breeds, origins and means of height at Withers in Males and Females.

\begin{tabular}{|c|c|c|c|}
\hline \multirow{2}{*}{ Breed } & \multirow{2}{*}{ Origin } & \multicolumn{2}{|c|}{ Height at Withers (cm) } \\
\hline & & Males & Females \\
\hline Afghan Hound (Palika 2007) & Afghanistan & $68-74$ & $63-69$ \\
\hline Azawakh (Standard-FCI N ${ }^{\circ}$ 307) & Mali & $64-74$ & $60-70$ \\
\hline Galgo (Standard FCI $N^{\circ}$ 285) & Spain & $62-70$ & $60-68$ \\
\hline Greyhound (FCI-Standard $\left.N^{\circ} \mathbf{1 5 8}\right)$ & England & $71-76$ & $68-71$ \\
\hline Saluki (Palika 2007) & Middle East & $58-71$ & $* * * * * *$ \\
\hline $\begin{array}{l}\text { Sloughi (Standard FCI } N^{\circ} 188 \text { ) } \\
\text { Tazi (Urosevic Milivoje } \text { et al., 2020) }\end{array}$ & $\begin{array}{c}\text { Morocco } \\
\text { Turkey }\end{array}$ & $\begin{array}{c}70 \\
62.02\end{array}$ & $\begin{array}{c}65 \\
58.38\end{array}$ \\
\hline
\end{tabular}


The results of our study were compared with those of other studies, it appears that animals in our Algerian sighthound sample set are higher than other hound breeds mentioned in Table 5, with Greyhound being the higher among the hound breeds listed in the table, this difference can be related at first to a possible genetic factors like the different genetic stocks of every breed, the different crosses made by the breeders, and secondly the effects of the environment where dogs live especially the altitude of every country cited in table 5. Other factors can be related to these differences like mountains, coastal plains, and highlands.

As for the impact of body coat color, the study was performed considering only 28 animals out of 30 because there was only a single dog with a pie coat color, and a single one with a tiger color, so they were excluded from the dataset for this analysis.

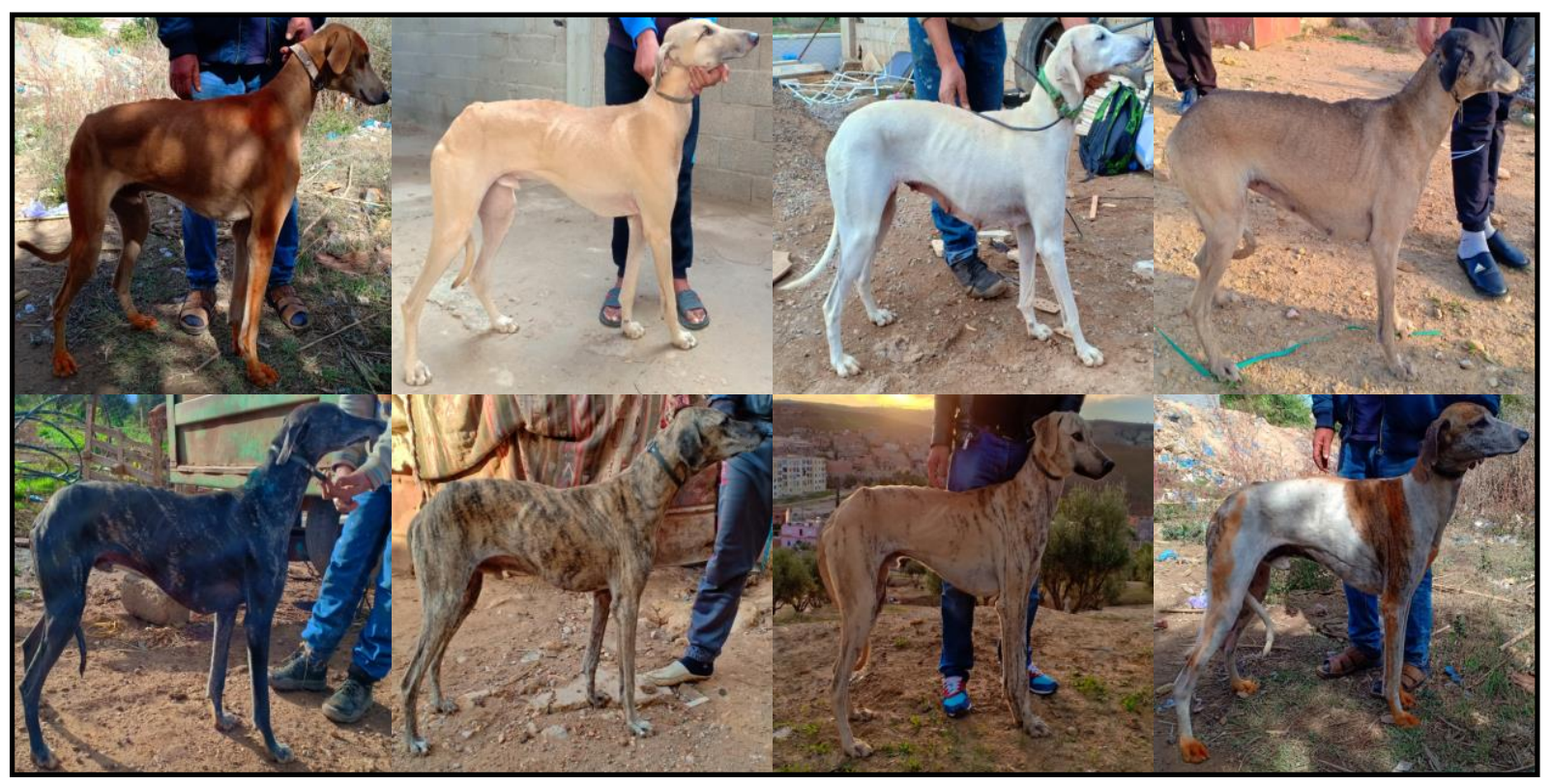

Figure 3. Different body coat colors distribution in studied population.

In figure 3, from up to down and from left to right the colors are (Brown, Dun, White, Grey, Dark Brindle, Light Brindle, Tiger and Pie).

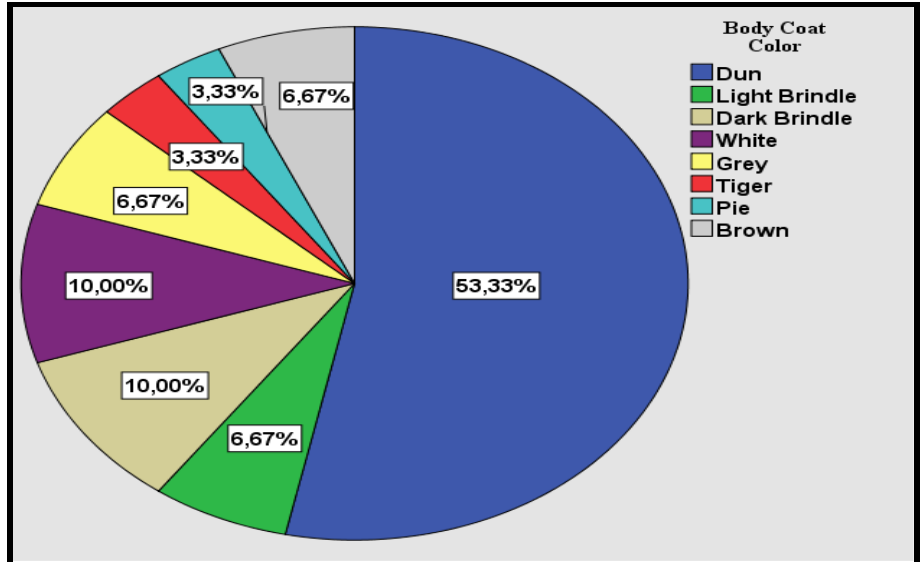

Figure 4. Body coat color distribution among the considered animals. 
According to Figure 4, we can notice that the dun color is dominant $(53,33 \%)$. Breeders prefer this color in both males and females compared to the others because the dun coat allow to more easily seeing the black coloration around eyes, what gives a unique charm to this breed according to the declarations of the breeders after their answers to our questionnaire. Regarding the impact of coat color on body measurements and body indices, the results are summarized in the table below.

Table 6. The impact on body coat color on body measurements and body indices.

\begin{tabular}{|c|c|c|c|c|c|c|c|}
\hline $\begin{array}{c}\mathbf{B C C} \\
\mathbf{N} \\
\end{array}$ & $\begin{array}{l}D \\
16 \\
\end{array}$ & $\begin{array}{c}\mathbf{L B} \\
\mathbf{2}\end{array}$ & $\begin{array}{c}\text { DB } \\
\mathbf{3} \\
\end{array}$ & $\begin{array}{l}\mathbf{W} \\
\mathbf{3} \\
\end{array}$ & $\begin{array}{c}\mathbf{G r} \\
2\end{array}$ & $\begin{array}{c}\mathbf{B r} \\
2 \\
\end{array}$ & Significance \\
\hline HW & $72,66 \pm 0,78$ & $74,60 \pm 3,00$ & $72,59 \pm 0,29$ & $65,86 \pm 1,81$ & $69,55 \pm 6,75$ & $69,90 \pm 4,50$ & ns \\
\hline HR & $71,63 \pm 0,79$ & $73,50 \pm 2,70$ & $71,06 \pm 0,46$ & $64,70 \pm 1,26$ & $66,85 \pm 6,45$ & $68,40 \pm 5,20$ & ns \\
\hline HL & $25,74 \pm 0,44$ & $25,65 \pm 1,55$ & $24,80 \pm 0,55$ & $24,56 \pm 0,93$ & $24,25 \pm 0,45$ & $23,50 \pm 1,10$ & ns \\
\hline ML & $11,00 \pm 0,22$ & $10,80 \pm 0,10$ & $11,40 \pm 0,40$ & $9,70 \pm 1,02$ & $11,20 \pm 0,10$ & $10,10 \pm 0,30$ & ns \\
\hline $\mathbf{E L}$ & $13,29 \pm 0,29$ & $12,80 \pm 1,10$ & $12,76 \pm 0,68$ & $13,20 \pm 1,45$ & $12,40 \pm 1,50$ & $13,10 \pm 0,20$ & ns \\
\hline NL & $21,36 \pm 0,43$ & $21,10 \pm 1,50$ & $20,93 \pm 0,60$ & $20,16 \pm 0,65$ & $19,30 \pm 3,00$ & $22,35 \pm 0,05$ & ns \\
\hline BL & $68,93 \pm 1,25$ & $69,10 \pm 1,50$ & $70,33 \pm 1,17$ & $65,86 \pm 4,03$ & $66,55 \pm 8,25$ & $67,80 \pm 1,50$ & ns \\
\hline TL & $43,32 \pm 10,03$ & $42,85 \pm 0,75$ & $46,96 \pm 0,92$ & $40,46 \pm 3,12$ & $44,55 \pm 7,15$ & $42,30 \pm 5,10$ & ns \\
\hline MC & $21,80 \pm 0,35$ & $22,55 \pm 3,15$ & $21,00 \pm 0,70$ & $20,26 \pm 1,02$ & $20,00 \pm 1,40$ & $20,75 \pm 0,95$ & ns \\
\hline HC & $33,86 \pm 0,54$ & $35,30 \pm 3,40$ & $34,46 \pm 0,65$ & $32,43 \pm 1,76$ & $32,55 \pm 1,05$ & $31,90 \pm 1,50$ & ns \\
\hline NC & $41,71 \pm 0,74$ & $43,25 \pm 2,50$ & $41,60 \pm 0,20$ & $37,96 \pm 2,53$ & $40,50 \pm 1,90$ & $39,00 \pm 1,80$ & ns \\
\hline $\mathrm{CC}$ & $73,53 \pm 0,78$ & $76,30 \pm 3,50$ & $77,53 \pm 2,34$ & $68,96 \pm 2,08$ & $71,80 \pm 3,40$ & $68,40 \pm 1,00$ & $*$ \\
\hline WtC & $48,76 \pm 1,11$ & $53,75 \pm 5,35$ & $52,76 \pm 3,73$ & $45,60 \pm 3,96$ & $44,45 \pm 1,05$ & $45,80 \pm 2,70$ & ns \\
\hline TC & $34,88 \pm 0,75$ & $34,60 \pm 2,80$ & $37,20 \pm 2,04$ & $30,70 \pm 1,48$ & $31,95 \pm 4,25$ & $33,30 \pm 1,80$ & ns \\
\hline FC & $14,86 \pm 0,26$ & $15,00 \pm 2,60$ & $15,03 \pm 0,40$ & $13,96 \pm 0,06$ & $13,70 \pm 1,90$ & $13,90 \pm 0,50$ & ns \\
\hline WC & $10,79 \pm 0,26$ & $12,75 \pm 0,05$ & $11,96 \pm 0,44$ & $10,66 \pm 0,29$ & $10,55 \pm 1,15$ & $9,75 \pm 0,45$ & ns \\
\hline IOF & $0,948 \pm 0,013$ & $0,927 \pm 0,023$ & $0,970 \pm 0,023$ & $0,998 \pm 0,039$ & $0,954 \pm 0,025$ & $0,972 \pm 0,041$ & ns \\
\hline IOM & $1,012 \pm 0,009$ & $1,022 \pm 0,005$ & $1,069 \pm 0,034$ & $1,047 \pm 0,022$ & $1,037 \pm 0,051$ & $0,981 \pm 0,048$ & ns \\
\hline IOB & $0,148 \pm 0,003$ & $0,144 \pm 0,005$ & $0,164 \pm 0,005$ & $0,162 \pm 0,004$ & $0,151 \pm 0,001$ & $0,139 \pm 0,002$ & ns \\
\hline IHN & $1,210 \pm 0,026$ & $1,216 \pm 0,013$ & $1,186 \pm 0,038$ & $1,218 \pm 0,017$ & $1,283 \pm 0,176$ & $1,051 \pm 0,051$ & ns \\
\hline IMH & $0,426 \pm 0,004$ & $0,422 \pm 0,025$ & $0,459 \pm 0,006$ & $0,392 \pm 0,026$ & $0,461 \pm 0,004$ & $0,430 \pm 0,007$ & $*$ \\
\hline IWR & $1,014 \pm 0,002$ & $1,014 \pm 0,003$ & $1,020 \pm 0,009$ & $1,017 \pm 0,008$ & $1,040 \pm 0,005$ & $1,022 \pm 0,011$ & ns \\
\hline
\end{tabular}

BCC: Body Coat Color, D: Dun, LB: Light Brindle, DB: Dark Brindle, W: White, Gr: Grey, Br: Brown, ns: no significant, *: Significant $(<0.05)$.

According to the ANOVA-test results, there were significant difference between individuals of different body coat color for CC and IMH, Dark Brindle and Light Brindle individuals had a more developed Chest circumference $(77,53 \pm 2,34 \mathrm{~cm}$ and $76,30 \pm 3,50 \mathrm{~cm}$ respectively) compared to the other coat color classes, so we can hypothesize that individuals of these two body coat colors have more breath than individuals of other body coat colors, because they have a more developed rib cage.

Regarding index of muzzle/head we can notice that grey individuals had the highest average compared to the other individuals of different colors, which means that in these grey individuals, the he length of the muzzle represents $46.1 \%$ of the total length of the head, so almost half of it, and this is what is mentioned in the Sloughi breed standard (that the length of the muzzle represents approximately $50 \%$ of the total length of the head).

We can propose that body coat color has no impact on all body measurements and all body indices among the population of Algerian sighthound raised in the Wilaya of Tlemcen, because breeders always said that the individuals with a dark body coat colors yielded higher body measurements then the individuals with a light body coat colors, which is not the case in our study. 


\section{Body measurements correlations}

Table 7. Pearson's Correlation matrix.

\begin{tabular}{|c|c|c|c|c|c|c|c|c|c|c|c|c|c|c|c|c|}
\hline & HW & HR & HL & ML & EL & NL & $\overline{B L}$ & TL & MC & $\mathrm{HC}$ & NC & $\mathrm{CC}$ & WtC & TC & FC & WC \\
\hline HW & 1 & & & & & & & & & & & & & & & \\
\hline HR & $0,983^{* *}$ & 1 & & & & & & & & & & & & & & \\
\hline HL & $0,633^{* *}$ & $0,635^{* *}$ & 1 & & & & & & & & & & & & & \\
\hline ML & $0,540^{* *}$ & $0,521^{* *}$ & $0,738^{* *}$ & 1 & & & & & & & & & & & & \\
\hline $\mathbf{E L}$ & $0,475^{* *}$ & $0,484^{* *}$ & $0,459^{*}$ & $0,414^{*}$ & 1 & & & & & & & & & & & \\
\hline NL & $0,562^{* *}$ & $0,561^{* *}$ & $0,390^{*}$ & $\mathbf{0 , 3 4}$ & 0,31 & 1 & & & & & & & & & & \\
\hline BL & $0,656^{* *}$ & $0,638^{* *}$ & $0,465^{* *}$ & $0,543^{* *}$ & $0,420^{*}$ & $0,553^{* *}$ & 1 & & & & & & & & & \\
\hline TL & $0,691^{* *}$ & $0,664^{* *}$ & $\mathbf{0 , 3 1}$ & $0,523^{* *}$ & $0,523^{* *}$ & $0,391^{*}$ & $0,754^{* *}$ & 1 & & & & & & & & \\
\hline MC & $0,523^{* *}$ & $0,518^{* *}$ & $0,631^{* *}$ & $0,459^{*}$ & 0,19 & 0,35 & 0,14 & 0,2 & 1 & & & & & & & \\
\hline HC & $0,599^{* *}$ & $0,576^{* *}$ & $0,720^{* *}$ & $0,578^{* *}$ & 0,21 & $0,387^{*}$ & $0,495^{* *}$ & $\mathbf{0 , 3}$ & $0,492^{* *}$ & 1 & & & & & & \\
\hline $\mathrm{NC}$ & $0,635^{* *}$ & $0,633^{* *}$ & $0,725^{* *}$ & $0,779^{* *}$ & 0,32 & $0,532^{* *}$ & $0,471^{* *}$ & $0,452^{*}$ & $0,633^{* *}$ & $0,716^{* *}$ & 1 & & & & & \\
\hline $\mathrm{CC}$ & $0,709^{* *}$ & $0,726^{* *}$ & $0,684^{* *}$ & $0,737^{* *}$ & $0,446^{*}$ & $0,441^{*}$ & $0,505^{* *}$ & $0,567^{* *}$ & $0,553^{* *}$ & $0,587^{* *}$ & $0,770^{* *}$ & 1 & & & & \\
\hline WtC & $0,443^{*}$ & $0,423^{*}$ & $0,511^{* *}$ & $0,546^{* *}$ & 0,2 & 0,27 & 0,15 & 0,24 & $0,663^{* *}$ & $0,644^{* *}$ & $0,689^{* *}$ & $0,597^{* *}$ & 1 & & & \\
\hline TC & $0,713^{* *}$ & $0,717^{* *}$ & $0,548^{* *}$ & $0,465^{* *}$ & $0,414^{*}$ & $0,491^{* *}$ & $0,375^{*}$ & $0,429^{*}$ & $0,497^{* *}$ & $0,559^{* *}$ & $0,660^{* *}$ & $0,773^{* *}$ & $0,565^{* *}$ & 1 & & \\
\hline FC & $0,701^{* *}$ & $0,729^{* *}$ & $0,606^{* *}$ & $0,576^{* *}$ & $0,576^{* *}$ & $0,619^{* *}$ & $0,672^{* *}$ & $0,596^{* *}$ & $0,434^{*}$ & $0,504^{* *}$ & $0,624^{* *}$ & $0,705^{* *}$ & $0,438^{*}$ & $0,635^{* *}$ & 1 & \\
\hline WC & $0,558^{* *}$ & $0,519^{* *}$ & $0,403^{*}$ & 0,35 & $0,424^{*}$ & 0,3 & $0,482^{* *}$ & $0,667^{* *}$ & 0,1 & $0,458^{*}$ & $0,409^{*}$ & $0,531^{* *}$ & 0,31 & $0,459^{*}$ & $0,503^{* *}$ & 1 \\
\hline
\end{tabular}

*: Significant $(\mathrm{p}<0.05), * *:$ Very significant $(\mathrm{p}<0.01)$.

According to the results presented in Table 7, we notice that all variables are positively correlated, although some correlations are not significant (bold values in the table).

The results of the principal component analysis (PCA) on body measurements showed that these variables presented $67.67 \%$ of the total inertia on axes 1 and 2 (Dim 1 and Dim 2).

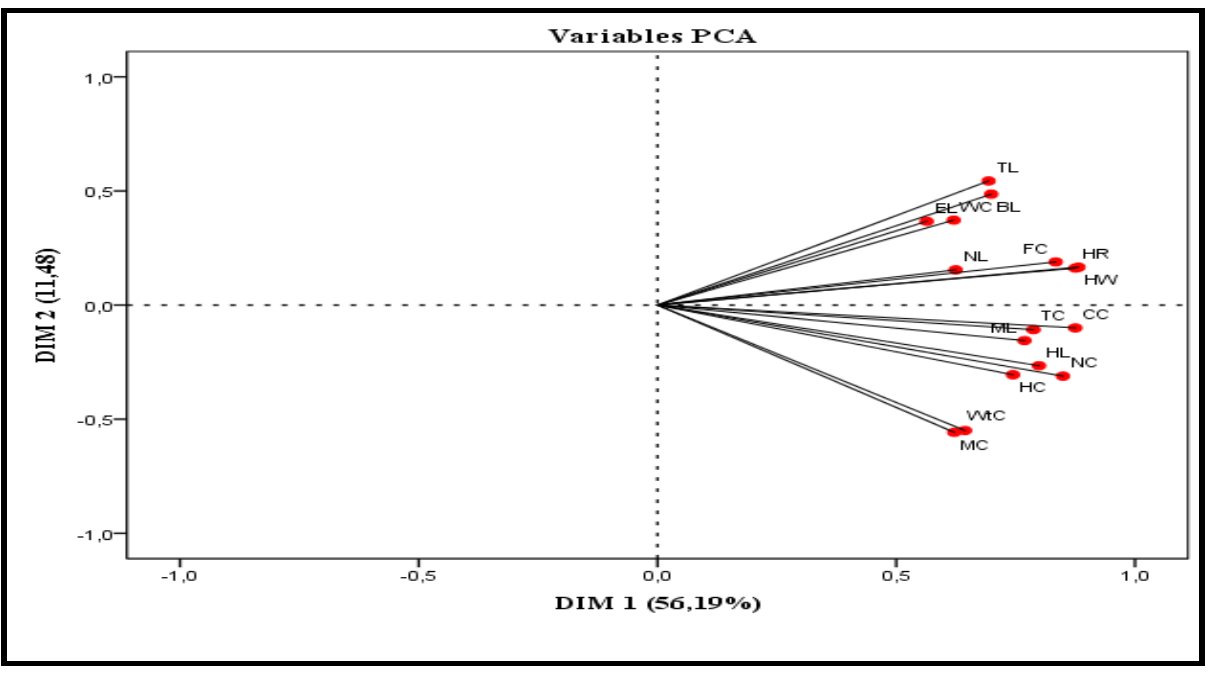

Figure 5. PCA of body measurements of the considered sighthound samples.

The graph represented by Figure 5 shows the formation of five groups of variables correlated positively, the first group contains (TL, BL, EL, and WC), the second contains (HR, HW, FC and NL), the third contains (CC, TC and ML), the fourth contains ( $\mathrm{NC}, \mathrm{HL}$ and $\mathrm{HC}$ ) and finally the fifth contains (WtC and MC)

All variables are correlated positively; there are no negative correlations between variables or groups. 


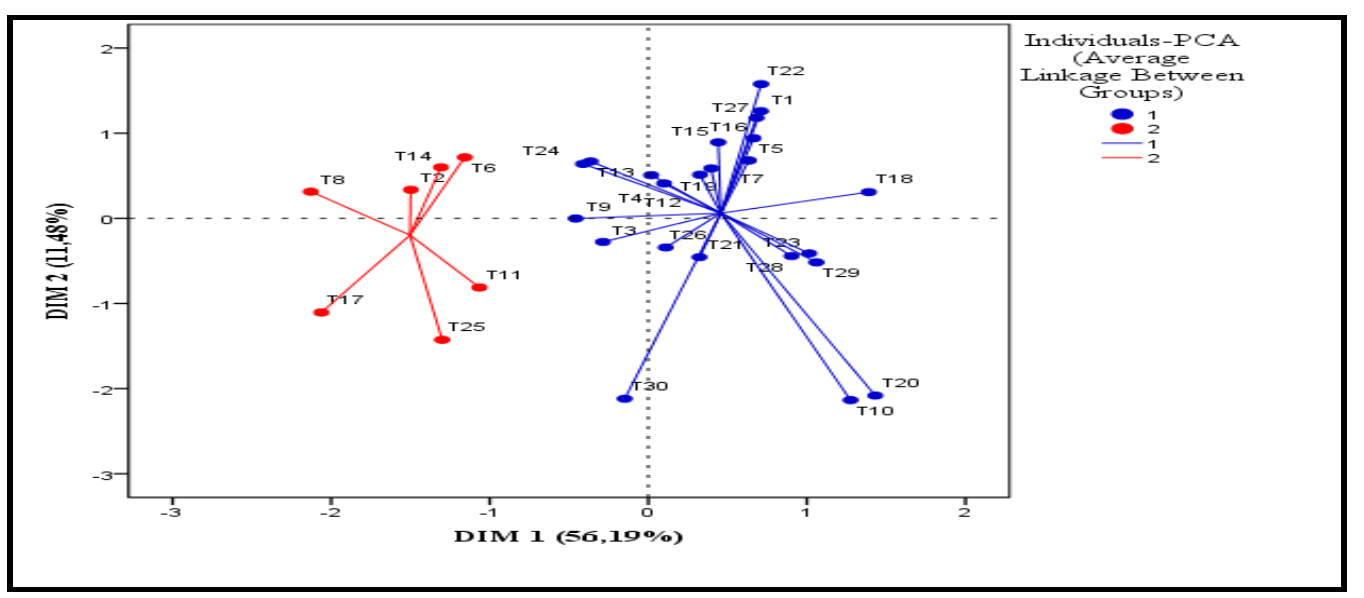

Figure 6. Individuals' representation of the considered sighthound samples using PCA.

The graphical representation of individuals using the PCA (Figure 6) shows that individuals from different zones are grouped according to their body measurements similarities and not according to their body coat colors, their sex, or their zones.

Using the results of Principal Component Analysis represented in Figure 6 and those of the Hierarchical Ascendant Classification represented in Figure 7, we can infer the presence of two different Classes of animals in the studied sample set; these classes are morphometrically heterogeneous which reflects a high rate of variability.

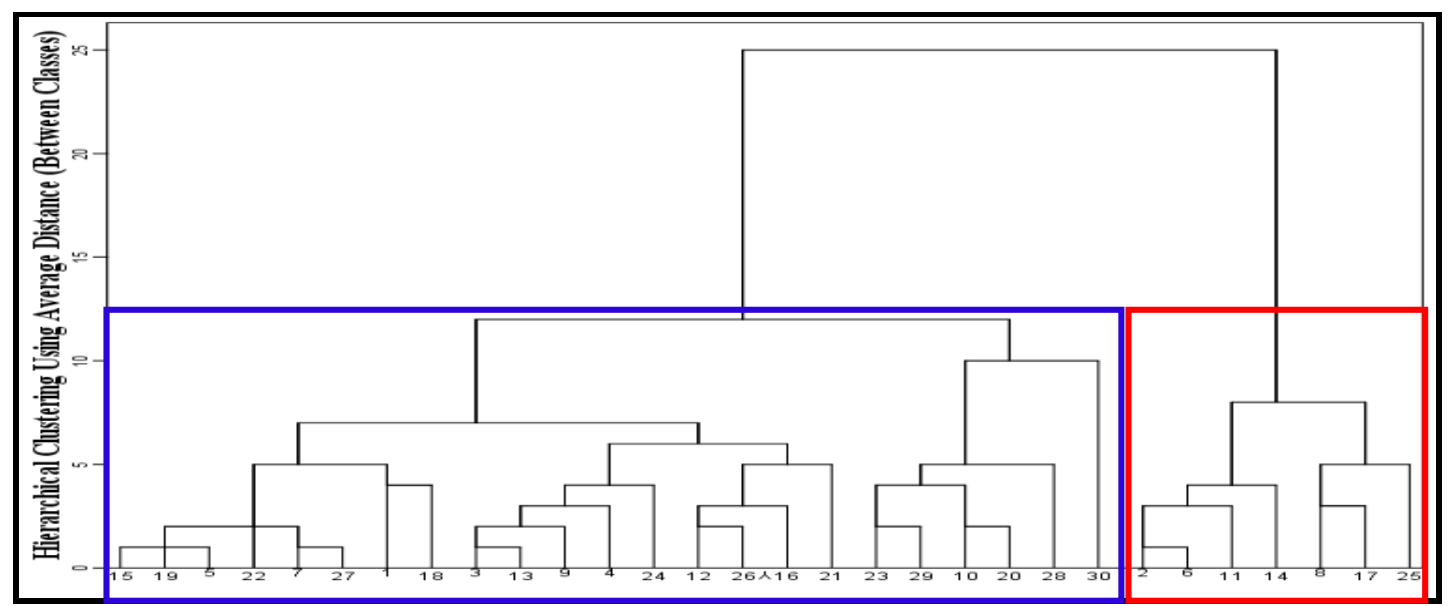

Figure 7. Hierarchical tree of Algerian sighthound using average distance (between classes). 
Table 8. Variations between classes identified by Hierarchical classification.

\begin{tabular}{lcc}
\hline & Class $\mathbf{C}$ & Class 2 \\
Sample size & $\mathbf{2 3}$ & $\mathbf{7}$ \\
\hline HW & $73,71 \pm 0,53$ & $64,49 \pm 1.05$ \\
HR & $72.48 \pm 0,54$ & \\
HL & & $23,31 \pm 0,39$ \\
ML & $25,83 \pm 0,29$ & $9,60 \pm 0.37$ \\
EL & $11,21 \pm 0,12$ & $12,14 \pm 0,38$ \\
NL & $13,47 \pm 0,22$ & $20,04 \pm 0,88$ \\
BL & $21,59 \pm 0,32$ & $62,41 \pm 1,57$ \\
TL & $70,28 \pm 0,68$ & $37,69 \pm 0,83$ \\
MC & $45,34 \pm 0,67$ & $19,93 \pm 0,68$ \\
HC & & $31,56 \pm 0,60$ \\
NC & $21,98 \pm 0,29$ & $37,61 \pm 0,74$ \\
CC & $34,27 \pm 0,44$ & $68,47 \pm 0,75$ \\
WtC & $42,39 \pm 0,48$ & $43,96 \pm 0,93$ \\
TC & $74,84 \pm 0,65$ & $30,97 \pm 0,87$ \\
FC & $50,19 \pm 0,98$ & $13,27 \pm 0,28$ \\
WC & $35,55 \pm 0,61$ & $9,89 \pm 0,26$ \\
\hline
\end{tabular}

According to the results shown in Table 8 we notice that individuals falling in the Class 1 yielded higher results for the all considered traits compared to individuals falling in the Class 2, so we can confirm that this classification of Algerian sighthound population raised in the Wilaya of Tlemcen shows no sexual dimorphism according to the different studied zones because males and females are present in both Class 1 and Class 2, the HAC result confirms the PCA observation (Figure 6).

Table 9. Shannon diversity index for the considered sample set.

\begin{tabular}{cc}
\hline Trait & SI \\
\cline { 2 - 2 } HW & 0,99193 \\
HR & 0,99839 \\
HL & 0,97067 \\
ML & 0,99839 \\
EL & 0,99193 \\
NL & 0,99839 \\
BL & 0,99193 \\
TL & 0,99839 \\
MC & 0,99193 \\
HC & 0,99839 \\
NC & 0,99839 \\
CC & 0,99839 \\
WtC & 0,99839 \\
TC & 0,99839 \\
FC & 0,97877 \\
WC & 0,99538 \\
Mean & $\mathbf{0 , 9 9 3 6 3}$ \\
\hline
\end{tabular}


The sixteen studied traits showed similar levels of diversity (between 0,97067 and 0,99839), and this can may be explained that these traits are probably controlled by genes which do not have a significant effect on the body (possibility of cumulative mutations in genes over generations). We can also notice that this index is relatively high which is probably a reflection of a significant genetic diversity.

\section{Conclusion}

The present study address for the first time the morphometric characterization of sighthound dogs in Algeria. The overall results of our study reveal that the Algerian sighthound (raised in the Wilaya of Tlemcen) is a big-sized sighthound dog, and the dun color is in the majority. This study has found that, generally, dogs of this breed are of square body, but there are varieties with other body shape. Within the observed population, which is, generally, square body shape; there are varieties with extremely shorter and extremely longer bodies relative to the height of the withers. This is very important, because when formulating an official breed standard, all possible variations of the index of format must be considered. This study shows also that the difference between the animals is due to their body measurement. This study represents a first step in the characterization of sighthound dogs in the West of Algeria; the study impact is currently limited by the restricted sampling area. Extending this approach to additional geographic areas will be needed to get a clear picture of the morphologic diversity of the considered breed and to get insights, possibly coupled with the study of molecular markers polymorphisms on the genetic diversity and genetic structure of the Algerian sighthound.

\section{References}

Capote J. Delgado JV. Fresno M. Camacho ME. Molina A 1998. Morphological variability in the Canary goat population. Small Rumin. Res., 27(2):162-7,

Crepaldi P. Negrini R. Milanesi E. Gorni C. Cicogna M. Ajmone-Marsan P 2001. Diversity in five goat populations of the Lombardy Alps: Comparison of estimates obtained from morphometric traits and molecular markers. J. Anim. Breed.Genet., 118(3):173-80

Crapon de Caprona D. Bernd Fritzsch B 2004. "Sloughi, Saluki, Saluqi...Genetic Data Help Separate Semantics From Evidence", in Dogs In Review, Hound Breeds Issue, ed. Bo Bengtson.

Keys D. 2004. "Kingdom of the Sands" in Archeology, Volume 57, Number 2.

Dossa LH. Wollny C. Gaul M 2007. Spatial variation in goats populations from Benin as revealed by multivariate analysis of morphological traits. Small Rumin. Res., 73(1):150-9

Drobnjak D 2012. Chien de berger turc Kangal, Cepib Pub-lisher; Zemun, Belgrade, Serbie.

Drobnjak D. Matic V. Miliyevic D 2010. Eksterijer pasa osno-ve procene, Tipo Štampa, Beogard, Serbie, pp: 27-33.

Germonpre M. Sablin MV. Stevens RE. Hedges REM. Hofreiter M. et al. 2009. Fossil dogs and wolves from Palaeolithic sites in Belgium, the Ukraine and Russia: osteometry, ancient DNA and stable isotopes. J Archaeol Sci. 36:473-90.

González A. Luque M. Rodero E. González C. Aguilera R. Jiménez J. Sepúlveda N. Bravo S. Herrera M 2011. Use of morphometric variables for differentiating Spanish hound breeds. Int. J. Morphol., 29(4):1248-1255

Herrera M. Rodero E. Gutierrez MJ. Peña F. Rodero JM 1996. Application of multifactorial discriminant analysis in the morphostructural differentiation of Andalusian caprine breeds. Small Rumin. Res., 2(1):39-47

Lanari MR. Taddeo H. Domingo E. Pérez M. Gallo L 2003. Phenotypic differentiation of exterior traits in local Criollo Goat Population in Patagonia (Argentina). Arch. Tierz., 46(4):347-56 
Luque M. Rodero E. Peña F. García A. Herrara M 2006. Application of discriminant analysis to the morphostructural differentiation of 7 extensive goat breeds. Annual meeting of the European Association for Animal Production. Uppsala, Sweden

Macciotta NPP. Cappio-Borlino A. Steri R. Pulina G. Brandano P 2002. Somatic variability of Sarda goat breed analysed by multivariate methods. Livest. Prod. Sci., 75(1):51-8

Marrube G. Cano E. Roldán D. Bidinost F. Abad M. Allain D. Vaiman D. Toaddeo H. Poli M 2007. QTL affecting conformation traits in Angora goats. Small Rumin. Res., 71:255-63

Palika L 2007. The Howell Book of Dogs: The Definitive Reference to 300 Breeds and Varieties. John Wiley \& Sons. 2007.

Pugnetti G 2001. Kopek Ansiklopedisi. Arkadas Yayinevi. Istanbul.

Rodero E. Herrera M. Peña F. Molina A. Valera M. Sepúlveda N 2003. Morpho-structural model for Florida and Payoya Spanish dairy goats in extensive (grazing) systems. Revista Científica -FCV-LUZ, 13(5):403-12

Urosevic M. Matejevic M. Drobnjak D. Ozkanal U 2020. Use of Morphometric Variables for Differentiating Breed Variations in Turkish Tazi (Sighthound) Population. Pakistan J. Zool., 52(5); $1765-1770$

Vargas S. Larbi A. Sánchez M 2007. Analysis of size and conformation of native Creole goats breeds and crossbreds used in smallholder agrosilvopastoral systems in Puebla, Mexico. Trop. Anim. Health Prod., 39(4):279-86

Yilmaz O 2017. Controversies of Origin of Domestic Dog - III - References of Modern Dogs until 2006. Scholars Journal of Agriculture and Veterinary Sciences 2017; 4(11):484-490.

Yılmaz O. Ertuğrul M 2011. SOME MORPHOLOGICAL CHARACTERISTICS OF TURKISHTAZI (SIGHTHOUND). The Journal of Animal \& Plant Sciences, 21(4): 794-799.

Zaitoun IS. Tabbaa MJ. Bdour S 2005. Differentiation of native goat breeds of Jordan on the basis of morphostructural characteristics. Small Rumin. Res., 56(1):173-82

Websites:

- $\quad$ http://www.fci.be/fr/FCI-la-plus-grande-organisation-canine-du-monde-90.html.

- https://www.larousse.fr/encyclopedie/images/L\%C3\%A9vrier/1003166 (Figure 2: Overview of body measurement points in this study).

- Breed Standards of the FCI:

- FCI STANDARD $N^{\circ} 158$.

- FCI STANDARD $N^{\circ} 188$.

- FCI STANDARD $N^{\circ} 285$.

- FCI STANDARD N 307 . 